Florida International University FIU Digital Commons

$12-3-2006$

\title{
Piano recital consisting of works by J. S. Bach, L. Van Beethoven and F. Chopin with extended program notes
}

Danica Borisavljevic

Florida International University

DOI: $10.25148 /$ etd.FI14051197

Follow this and additional works at: https://digitalcommons.fiu.edu/etd

Part of the Music Performance Commons

\section{Recommended Citation}

Borisavljevic, Danica, "Piano recital consisting of works by J. S. Bach, L. Van Beethoven and F. Chopin with extended program notes" (2006). FIU Electronic Theses and Dissertations. 1735.

https://digitalcommons.fiu.edu/etd/1735 
FLORIDA INTERNATIONAL UNIVERSITY

Miami, Florida

PIANO RECITAL CONSISTING OF WORKS BY J. S. BACH, L. VAN BEETHOVEN AND F. CHOPIN WITH EXTENDED PROGRAM NOTES

A thesis submitted in partial fulfillment of the requirements for the degree of

MASTER OF MUSIC

by

Danica Borisavljevic

2006 
To: Dean Juan Antonio Bueno

College of Architecture and the Arts

This thesis, written by Danica Borisavljevic, and entitled Piano Recital Consisting of Works by J.S. Bach, L. van Beethoven and F. Chopin with Extended Program Notes, having been approved in respect to style and intellectual content, is referred to you for judgment.

We have read this thesis and recommend that it be approved.

Jose Lopez

Joel Galand

Joseph Rohm

Kemal Gekic, Major Professor

Date of Defense: December 3, 2006

The thesis of Danica Borisavljevic is approved.

Dean Juan Antonio Bueno

College of Architecture and the Arts

Dean George Walker

University Graduate School

Florida International University, 2006 
ABSTRACT OF THE THESIS

PIANO RECITAL CONSISTING OF WORKS BY J.S. BACH, L. VAN BEETHOVEN AND F. CHOPIN WITH EXTENDED PROGRAM NOTES

by

Danica Borisavljevic

Florida International University, 2006

Miami, Florida

Professor Kemal Gekic, Major Professor

Partita No 4 in D Major, BWV 828..................Johann Sebastian Bach (1685-1750)

Sonata No 23 in F minor, Op 57...................udwig van Beethoven (1770-1827)

Scherzo No1 in B minor, Op 20..................Frederic Chopin (1810-1849) 


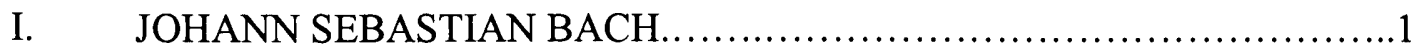

Biography............................................................

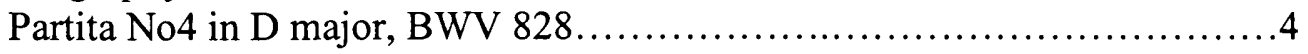

Historical Background................................................ 4

Analysis................................................................. 4

II. LUDWIG VAN BEETHOVEN .....................................

Biography.......................................................

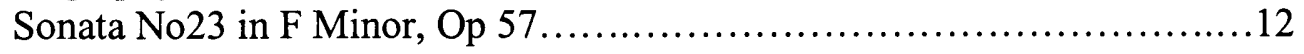

Historical Background................................................

Analysis..........................................................13

III. FREDERIC CHOPIN ...............................................

Biography............................................................

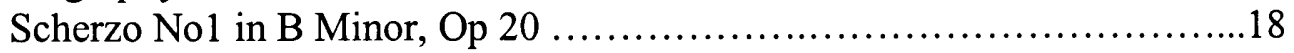

Historical Background............................................. 18

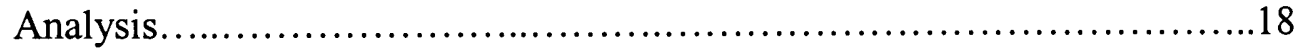

LIST OF REFERENCES...................................................20 


\section{JOHANN SEBASTIAN BACH}

Biography:

Johann Sebastian Bach's music brought the Baroque period to its ultimate maturity. The intellectual depth, technical command and artistic beauty of his music altogether made him one of the greatest composers of his time. J. S. Bach was a member of one of the most extraordinary musical families of all time. For many years, members of the Bach family living throughout Thuringia held positions such as organists, town instrumentalists, or cantors, and the family name enjoyed a wide reputation for musical talent. Bach's father was a talented violinist and trumpeter and all of Bach's uncles were professional musicians. Bach's eldest brother, Johann Christoph Bach, the organist in Ohrdruf, supposedly taught young J. S. Bach to play the clavichord. At the age of 14, J.S. Bach began to study at the prestigious St Michael's School in Lüneburg. During this period he met Georg B_hm, organist of the Johanniskirche at Lüneburg, who had been a pupil of the famous organist Jan Adams Reineken in Hamburg. Böhm introduced J.S. Bach to the organ tradition of Hamburg. J. S Bach's first "serious" job was in Arnstadt, in 1703. He became organist of the Neue Kirche, where he stayed till 1707 . He already built a reputation as a young organ virtuoso and his new appointment was in Mülhausen, where he obtained the position of organist. There he wrote many of his great organ works, such as the Toccata and Fugue in D minor. The small town of Mülhausen was not too satisfying for young and aspiring Bach. After a year spent there, he moved to 
Weimar, which presented a significant step forward in his career. Wilhelm Ernst, Lutheran ruler and a sponsor of the court music, hired Bach as an organist and member of the orchestra. At Weimar, Bach had an opportunity to compose for the Duke's ensemble as well as playing organ. His steady output of fugues started in Weimar with the first book of the Well-Tempered Clavier. This monumental work, containing 48 preludes and fugues ( 24 in each book), is one of the best examples of contrapuntal writing of the time. In Weimar, Bach made various transcriptions of Italian material, which represents a decisive moment in his development. From now on, he combined his early contrapuntal writing with its northern German and French influences, with Vivaldi-like thematic development and harmonic planning. Bach's fame as an organist began to extend far beyond Weimar but certain political tensions on the Duke's court made Bach search for a more stable position. He moved from Weimar in 1717. Bach's new position was in Cöthen as a Kapellmeister (director of music) at the court of his new patron, Prince Leopold von Anhalt- Cöthen. Prince Leopold was a music enthusiast who appreciated Bach's talent, giving him a lot of freedom and a good salary. The Prince was also a Calvinist, so he didn't use elaborate music in his worship, and therefore most of Bach's music from this period is secular. The "Cöthen" period represents a culmination point in Bach's chamber music output. The Brandenburg concerti, as well as partitas for solo instruments and many orchestral suites, date from this period. In 1719 Bach went to Berlin to get a great Mietke harpsichord for the court, which greatly stimulated his keyboard output. Bach's famous French and English suites were also written in Cöthen. 
In 1723 Bach moved to Leipzig, where he was the Musical Director in St. Thomas Church. His post required him to provide weekly music at the two main churches in Leipzig and to teach in the St. Thomas School. The St. Thomas School had a long choral tradition, so Bach's main duty in the school was to rehearse the student choir. Part of his duties required him to write a new cantata every week. What is so astonishing about Bach is that his cantatas were a result of certain routines, but they are masterpieces nevertheless. In the early Leipzig days he composed the St. John Passion, the St. Matthew Passion and the Magnificat. However, the material situation in the church and at the school was less than ideal, resulting in Bach's constant conflicts with many authorities. In 1729 Bach turned to other musical projects, finding them more challenging. One of the projects was the Collegium Musicum (Music Society), an orchestra of students and some professional musicians, founded by Telemann in 1702. Bach was the director of this society till the early 1740 's, with some interruptions between 1737 and 1739 . Concerts were held once a week at Zimmermann's Coffee House at Katharinenstrasse 14. The Bach leadership of the orchestra produced a rich output of chamber music. Another crucial point of this period of Bach's life was his new appointment as court Kapellmeister in Dresden, 1736. He didn'thave any specific duties there, but the connection with Dresden, a city with very rich musical life, had become important for Bach. Dresden was a place where new styles were in fashion, such as the galant style. Bach started to incorporate these new stylistic devices into his pieces, but still holding to stile antico, the strict counterpoint in the style of Palestrina. The influence of gallant style is visible in several of the Goldberg Variations (as a part of Clavierübung IV) - less dense polyphonic structure and the emphasis on the melody. 
Historical background:

Bach started publishing his Partitas around 1726, and in 1731, the whole collection of six were published as a first part of Clavierübun, BWV 825-830. His Clavierübung represents a series of keyboard music, divided into four parts. The second part of Clavierübung contains the Overture in the French Manner (BWV 831) and the Italian Concerto (BWV 971), the third part consists of twenty seven movements for organ (BWV 522, 669-689, 802-805)) and the fourth part is the Goldberg Variations (aria with diverse variations, BWV 988). Although in earlier days "partite" meant a set of variations, Bach's concept of a partita is a suite based on dances, mostly French ones. The Partitas are Bach's first published work (his Op.1), and represent the culmination in Bach's keyboard output. Partita No.4 in D major BWV 828 is a set of seven movements in the form of dances.

Analysis:

\section{Overture}

The Partita begins with the Overture, which consists of a dramatic and slow first part and a fugue-like polyphonic second part. Bach also changes the meter between the two parts of the Overture, making the switch between them more dramatic and sudden. The slow part of the Overture has a typically dotted rhythm and off-beat passages in the tradition of a French Overture. 
J. S. Bach: Partita No.4 in D major BWV 828, Ouverture (measures No1 -2.)

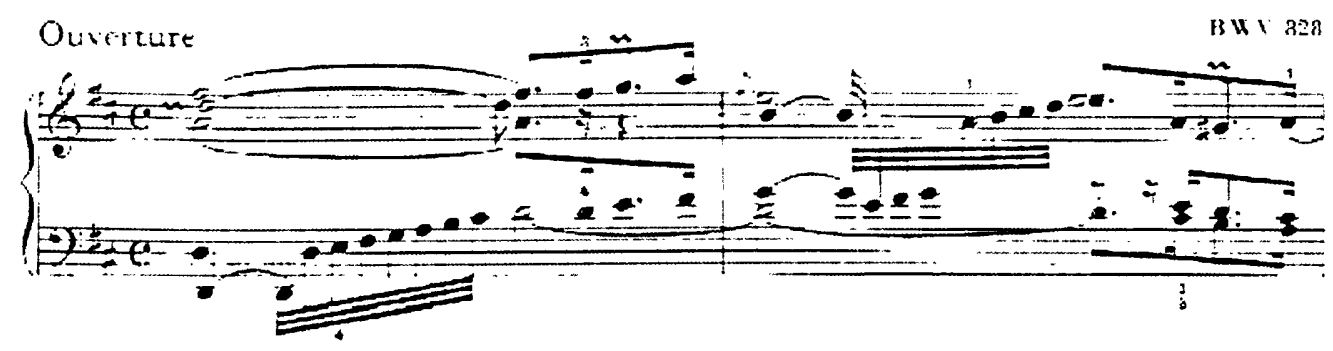

\section{Allemande}

Bach's Allemande is a perfect example of a traditional allemande - a dance originated in the $16^{\text {th }}$ century. It is in $4 / 4$ meter, beginning with an upbeat, in moderate tempo and in binary form. Its calm and steady character is preserved through tonal unity and scale-like passages. Harmonically, this allemande is clearly in D major with few modulations into close tonalities (for example: first half ends in A major which is a dominant key).

Courante

The Courante was probably one of the most popular dances at the French court of Louis XIII, where it originated. The Courante appeared far more often in the music for lute and harpsichord than any other dance of that time. Its metrical ambiguity is one of the most intriguing qualities of the Courante, especially in this one. It is written in $3 / 2$ meter but Bach uses internal shifts between $3 / 2$ and $6 / 4$ meters during the piece in an enigmatic way.

J. S. Bach: Partita No.4 in D major BWV 828, Courante (measures 1 - 2.) 


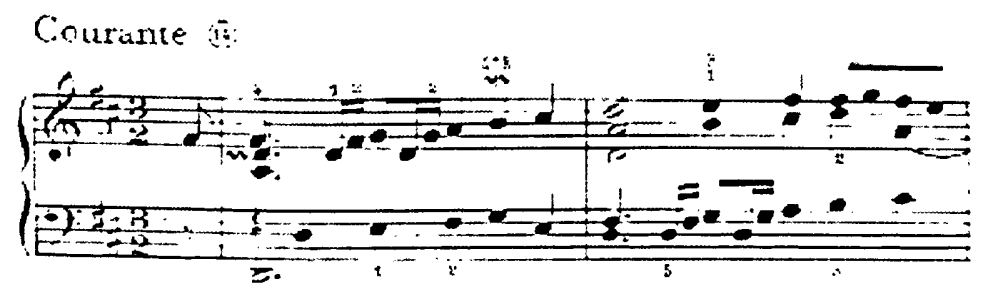

Aria

This lively movement can be easily pictured as a flute piece accompanied by a lute of harpsichord. There is more emphasis on the melody that in other stylized dances. The melody also appears in the left hand, which suggests a duo.

J. S. Bach: Partita No. 4 in D major BWV 828, Aria (measures 10 - 12.)

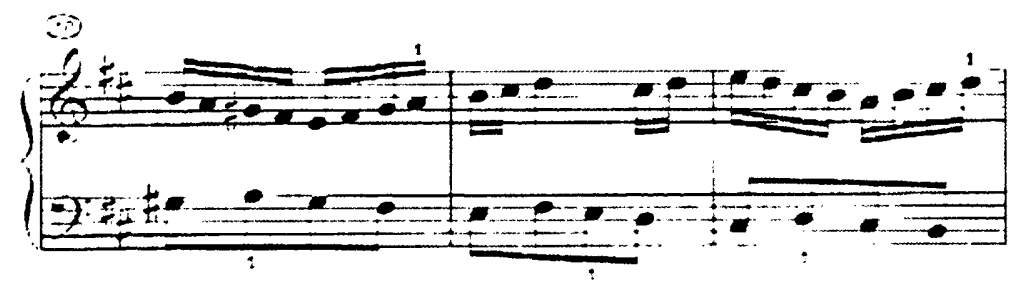

Sarabande

The Sarabande had a long history, having its roots in Spanish folk songs. Originally it was a dance accompanied by guitar and castanets, with a singing part. It appeared in Italy in the early $17^{\text {th }}$ century as an exotic and colorful dance. Considering its origin, the Sarabande is a highly expressive piece, with embellished melody and several contrasting moods within the piece. Music theorists agree that the tempo of the Sarabande is slow, if not very slow, with the use of tempo rubato, a device well known to the Romantics, but 
obviously a well-known device far before Chopin. Bach's Sarabande starts with a dramatic opening gesture, where the strongest accent falls on the second beat of the measure. The second beat of the measure is a suspension, creating the dissonance as D in the upper voice is against $\mathrm{E}$ in the bass. After this impressive beginning, the melody starts to gradually develop into scalar passages of exquisite beauty. The second part of the Sarabande has a similar beginning (the same dramatic suspension) but it is followed by a modulation in B minor. Gradually building tension with the rising passages and intense intonation in the melody, the second part of a Sarabande seems like a short development section of a sonata form (on a much smaller scale), as the reprise of the first part of the sarabande follows it, although varied.

J. S. Bach: Partita No. 4 in D major BWV 828, Sarabande (measures 1 - 2.)

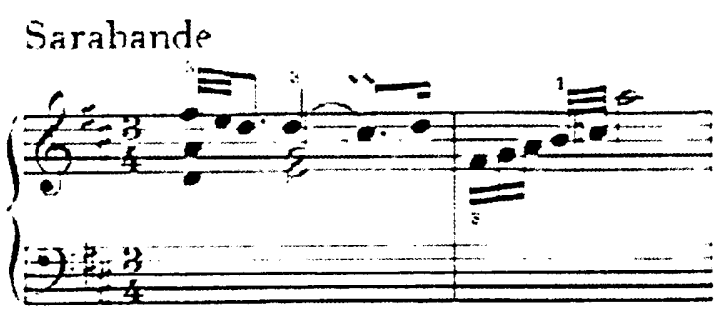

Menuet

The Menuet is a dance well known by its noble character and elegant simplicity. Moderate in character, it does not exhibit extremes of moods and emotions like the sarabande or the virtuosity of a gigue. Distinctive of this Menuet is its rhythmic complexity - alternation between duplet and triplet figures, sometimes simultaneously. 
Also, there is a dotted sixteen figure in the left hand and a triplet in the right hand. Most performers play the second note of the dotted figure together with the last note of a triplet, instead of playing the dotted note after the triplet.

\section{J. S. Bach: Partita No. 4 in D major BWV 828, Menuet (measures 7 - 8.)}

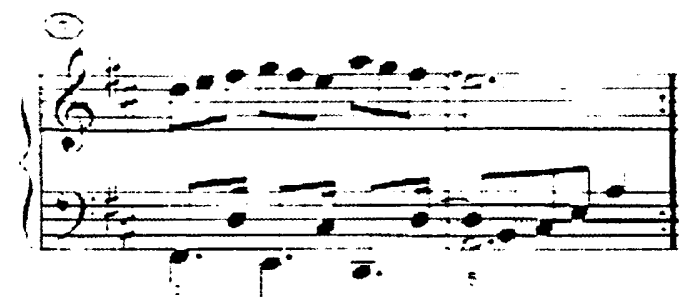

Gigue

This dance is a fast dance in a triple meter but this Gigue is unique for its time signature 9/16. There is no evidence that any other composer except Bach used this time signature for a gigue. In this Gigue there is more textural variety that in any other movement of the Partite. The Gigue starts with a 6 measure long subject, emerging into a three-voice fugue. The subject arrives in the middle voice, followed by an upper voice and finally, the bass.A rising sequence (measures 21-24) builds the tension through the Gigue. The second part of the Gigue begins with a new subject. When the answer appears in the upper voice, the first subject appears simultaneously as a countersubject. The second part of the Gigue brings more technical difficulties regarding polyphony. In measures 78-85 the right hand has to play two voices of which the upper voice should be held throughout the whole bar while the middle voice has sixteenth notes. This requires rather 
uncomfortable "baroque" fingering, such as playing two consecutive notes with the thumb in fast tempo, necessary for execution of this tour the force of a genre.

\section{LUDWIG VAN BEETHOVEN}

Biography:

Ludwig van Beethoven was baptized on December 17, 1770 at Bonn. His family originated from Belgium, and both Beethoven's father and grandfather were musicians. At an early age, Beethoven showed an interest in music. An extraordinary gift was at first discovered by his father Johann, who is considered to be Ludwig's first music teacher. Beethoven played his first recital at the age of 7 , and, according to the public announcement, he was playing "various clavier concertos and trios." Shortly after that, his father sent Beethoven to receive more serious musical education so Beethoven started taking lessons from an old court organist van den Eeden and Tobias Friedrich Pfeiffer. It is known that, on these lessons, Beethoven received basic theory knowledge, keyboard instruction and violin and viola lessons. The turning point in Beethoven education was the arrival of a famous musician, Christian Gottlob Neefe, in Bonn. It is not clear at what point Beethoven started to take lessons from Neefe, but a short paragraph in Cramer's Magazin der Musik, written by Neefe, shows Beethoven as a "most promising talent." Soon after, Beethoven was appointed as Neefe's assistant. At that time, Beethoven 
already had a reputation of a virtuoso. He often played recitals and probably due to his concert activity, there is little evidence of activity as a composer.

The year of 1792 was a defining moment in Beethoven's career. That year he arrived in Vienna. Beethoven traveled to Vienna before and supposedly took lessons from Mozart. Beethoven's purpose of coming to Vienna was to take instructions from Haydn. Beethoven took lessons from Haydn for a year after he went to another instructor Johann Georg Albrechtsberger, one of the best teachers of counterpoint in Vienna. The third important figure at his point of Beethoven's life was Antonio Salieri who had a custom of teaching for free those students he considered talented. Beethoven already established himself in Viennese circles as a composer and a pianist. Connections with aristocratic circles helped him have a steady income and the opportunity to give concerts in private houses. He was well known for his improvisational skills. His career as a composer was progressing as he played pieces such as the First and Second concertos for piano. In the year of 1797 he published his opera 5 through 8 , of which the most important was the piano sonata in E flat Major Op. 7. Important pieces of this period are the piano sonatas Op. 13 ("Pathétique") and the famous "Moonlight" Sonata, with its "romantic" quasi-improvisatory first movement and turbulent virtuoso third movement. This is known as Beethoven's "early period" culminating with the Second symphony in 1802. This is also the time when his "middle period" started. In this period Beethoven searched for a new expression, resulting in a more individual style. In this period Beethoven started to work on the transformation of sonata form, changing its form to fit to his imagination. Somewhere around 1801, Beethoven discovered that he was losing his 
hearing. This resulted in a personal crisis, as evidenced in the Heiligenstadt Testament written to his brothers in 1802 . His illness affected his social life to a great extent. He found it difficult to handle social interactions, bursting into outbreaks of anger. But in spite of the personal troubles and his illness, this period was a period of great pieces such as the Symphonies No. 3- No. 8 and the Fifth Concerto for piano. Beethoven started to explore non-musical ideas, such as heroism, evident in the Symphony No 3 ("Eroica") and the piano sonatas Op. 53 ("Waldstein") and Op 57 ("Appassionata"). Personal difficulties arose again, apparent in a letter to the "immortal beloved", a mysterious woman for whom Beethoven felt deep affection. It was never discovered who was that woman but this episode of Beethoven's life shows him as a passionate man capable of deep feelings. The "late period" started around 1813. Family issues seemed to distract Beethoven from work. His brother died in 1815, leaving a wife and son Karl behind him. Karl was nine years old and his father's wish was that both, his wife and Beethoven take care of him. Beethoven couldn't respect that wish and started a battle over custody. Beethoven won but soon he experienced difficulties raising a child. This was a burdened and tensed relationship, especially when Karl got older. Apart from two cello Sonatas (Op. 102) that Beethoven wrote in the second half of 1815 , most of his pieces were not of such importance. At that time, Beethoven was already completely deaf, using various devices to make his life as a musician possible. The Czech Johann Nepomuk Maelzel, the inventor of the metronome, tried to help Beethoven with his hearing with acoustic cornets and a listening system linking up the piano. But it was the inner strength that made Beethoven capable of working, despite his deafness. In 1816 Beethoven wrote the first of his last five piano Sonatas, the Sonata Op. 101. This sonata is a typical example of 
Beethoven's late period, where he experiments with sonata form, resulting in either condensed or extremely long movements (in this case a really short first movement) and also in the use of complex polyphony, especially a fugue as part of development sections. The Sonata Op. 106, a gigantic piece known as "Hammerklavier Sonata", also shows a similar approach. Free treatment of form here results in oversized movements, especially its third movement (Adagio) which is the longest slow movement that Beethoven ever wrote for piano. In the last three sonatas - Op. 109, Op. 110 and Op. 111, Beethoven develops another important element of his late period - variations. Although variations had been present throughout all his life, variations in his late period sonatas become more individual and a deeply profound review of a theme. The theme becomes transformed rather than just varied. The free approach to sonata form, subjective treatment of variation and use of complex counterpoint opens future horizons to the coming Romantics.

SONATA NO 23 IN F MINOR, OP. 57

Historical background:

The piano sonata in F minor, Op. 57 (“Appassionata”) was completed around 1806 and published in 1807. Beethoven's editor Cranz applied the name "Appassionata" and there is no evidence that Beethoven requested it. The Sonata consists of three movements, preserving unity through thematic relationships. 
Analysis:

$1^{\text {st }}$ movement: Allegro Assai - Piu Allegro

The group of the first theme consists of the theme and two motifs. The first theme is repeated by a half step up, which is an unusual practice in classicism as there is usurpation of a tonality ( $\mathrm{F}$ minor) on the very beginning. This might be an intention to make an impression of improvisation, as Beethoven was well known for his improvisational skills. The relation of the $2^{\text {nd }}$, as a true Neapolitan relation, Beethoven uses throughout the Sonata. The second motif is the "fate" motif that Beethoven also uses in the $5^{\text {th }}$ Symphony. The second theme is hymn-like and peaceful, creating a contrast with the $1^{\text {st }}$ theme.The third important element of the exposition is a tumultuous episode (measures 51-60), which can't be called a theme but despite that brings some new thematic material. The development section consists of material used in the exposition. The $1^{\text {st }}$ theme is fragmented through a technically difficult episode where it is combined with flourished figuration in the other voice. The second theme appears this time in D flat major, followed by a turbulent figuration combined with the second motif of the $1^{\text {st }}$ theme, leading to the reprise. The beginning of the reprise is varied, as there is a consistent eight-note figuration on a dominant bass. Piu allegro is a coda, using second theme as the main material. The finishing measures of the movement bring fragments of the $1^{\text {st }}$ theme. 
L. van Beethoven: Sonata Op. 57 in F minor, 1st movement, first theme (measures 1-4.)

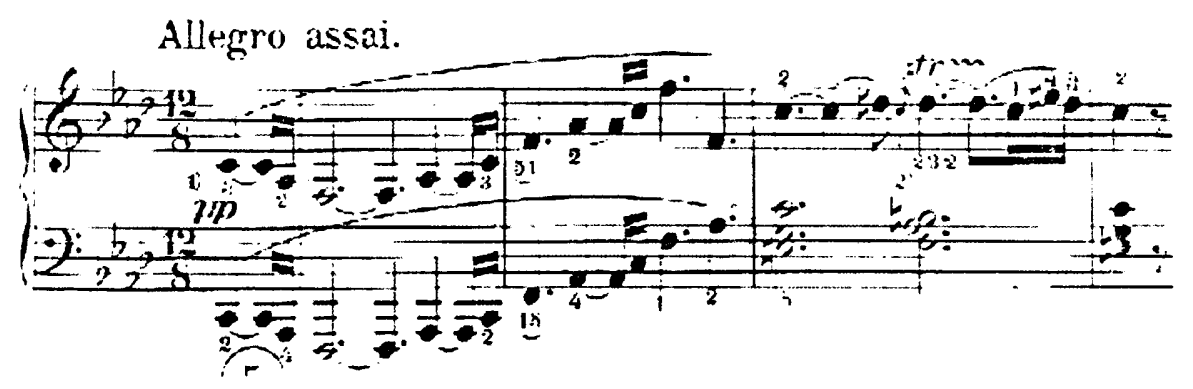

L. van Beethoven: Sonata Op. 57 in F minor, 1st movement, fragment of the second theme (measures $35-37$.)

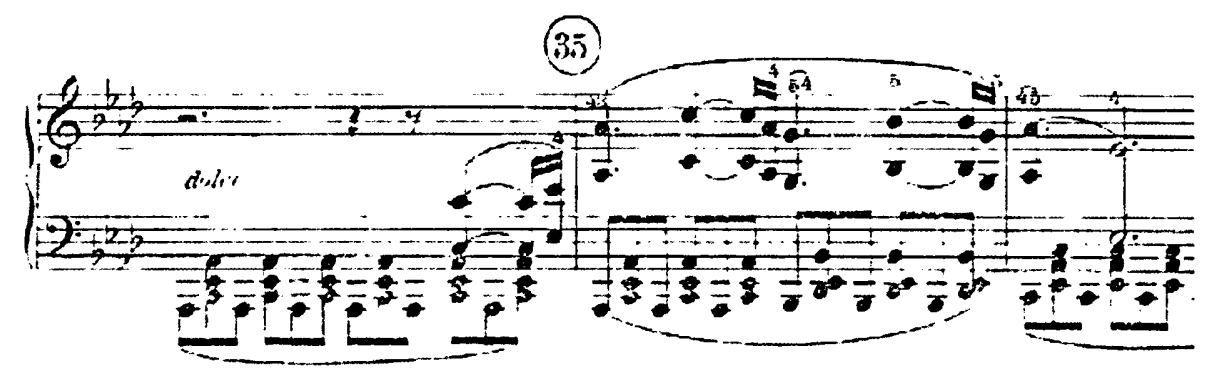

$2^{\text {nd }}$ movement: Andante con moto

The second movement presents a theme with variations. The theme of this movement is intimate and rather simple, creating a great contrast with the $1^{\text {st }}$ movement. The second variation starts on the offbeat creating a syncopation, which makes a unique effect. Adding a figuration in the other voice and combining it with the theme, the subsequent variations gradually become more complex and richer in sound further developing this movement. 
L. van Beethoven: Sonata Op 57 in F minor, $2^{\text {nd }}$ movement; fragment of the theme (measures 1 - 8.)

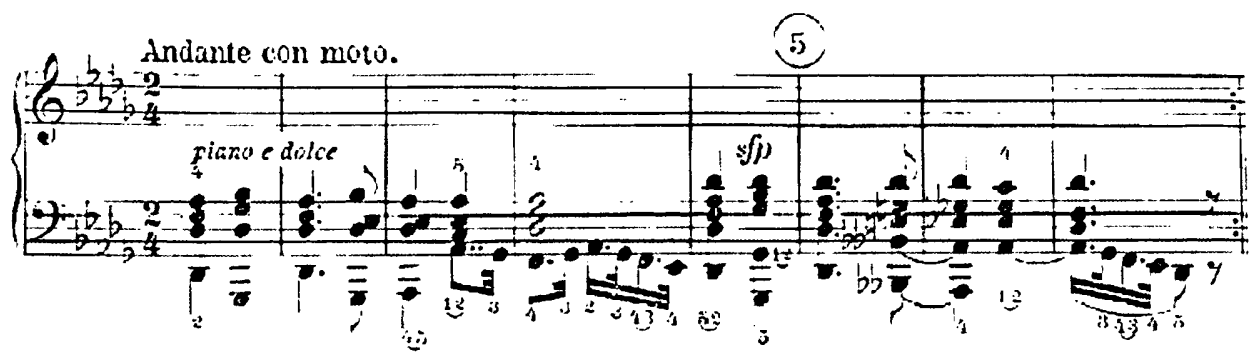

$3^{\text {rd }}$ movement: Allegro ma non troppo

The third movement is in sonata-allegro form in which second part is marked to repeat.

This movement creates the impression of a perpetum mobile because of its constant sixteen-note figuration that doesn't stop till the coda (Presto). The $1^{\text {st }}$ theme starts after a short introduction. The F minor triad in the $1^{\text {st }}$ theme of the $1^{\text {st }}$ movement is inverted, creating the $1^{\text {st }}$ theme of the $3 \mathrm{rd}$ movement. The theme is present almost throughout the whole movement, which creates an atmosphere of an obsession and despair as one idea is constantly repeated. The second theme modulates to $\mathrm{C}$ minor. Themes are not as contrasting as in $1^{\text {st }}$ the movement, which brings a more unified tone picture. The development section starts in measure 117 with the varied $1^{\text {st }}$ theme (arpeggiated diminished chord instead of a tonic triad). The recapitulation doesn't bring any new material although there is a sudden modulation to D-flat major through its dominant (III of F minor, measure 260). Beethoven adds Coda, a brilliant and technically difficult part, marked Presto where he uses both new material (measures 308-323) and the first theme. 


\section{FREDERIC CHOPIN}

Biography:

Frederic Chopin's musical talent was evident early in his life. At the age of seven, he already wrote two polonaises (in G minor and B flat Major) One year later, he gave his first piano recital. He gained reputation as a "second Mozart," becoming an attraction at the aristocratic salons of Warsaw. From 1823 to 1826 Chopin attended the Warsaw Lyceum where his father was one of the professors. In this period of his life, Chopin revealed his interest in folk music and country traditions. He became familiar with folk music and started exploring its authentic form, richness of rhythm and distinct tonality. Inspired by folk music, Chopin wrote his first Mazurkas in 1825. In 1826 Chopin began studying at the Warsaw School of Music. There he studied composition and music theory. Among the works he wrote as a student are the Piano Sonata in $\mathrm{C}$ minor, the Variations Op. 2, the Rondo à la Krakowiak and the Fantasie Op. 13. After completing his studies in 1829 , Chopin devoted himself to a performance career and started presenting his pieces to a larger audience. A short trip to Vienna, where he played his Variations Op. 2 and the Rondo à la Krakowiak Op. 14, resulted in atremendous success. Another important event for Chopin was the printing of his scores in Vienna as this is the first time that his music had been printed outside Bohemia. After a trip to Vienna, Chopin returned to Warsaw and started to work on his two piano concertos. Both Concertos (in E minor No.1 Op. 11 and in F minor No. 2 Op.21) represent masterpieces in the genre of the piano concerto. Their premiere was at the National Theatre in Warsaw. This was a time when Chopin showed great productivity creating his etudes, nocturnes and waltzes. 
Having already established a career in Bohemia, Chopin decided to move to Vienna. Having given a farewell recital at the National Theatre at Warsaw, he played his Concerto in E minor. But soon after moving to Vienna, the Russo-Polish war started, placing Chopin in a difficult position. He stayed in Vienna for a couple of more months working on his Etudes Op. 10 and Scherzo Op. 20. In 1831 Chopin arrived to Paris where he stayed to the end of his life. There, his reputation as an artist grew rapidly. Chopin made contacts with his fellow émigrés, such as poet A. Mickiewitz, whose poems inspired Chopin's Ballades. He also became a member of the Polish Literate Society. Paris at 1830's was an artistic place with a busy musical life. In Paris Chopin met and became friends with Liszt, Mendelssohn and Berlioz. Chopin participated in several concerts during his living in Paris, playing solo or with other artists. In 1833 Chopin played Bach's Concerto for three harpsichords together with Liszt and Hiller. Another important fact telling more about Chopin's personality is that Chopin never actually liked to perform in large halls, like Liszt. He preferred the small and intimate setting of salons, where he could share his personal thoughts through music with his friends. This was also the time when he showed the signs of tuberculosis. This disease eventually ended his life at the age of 39 , making his life as a performing artist more and more difficult, as the disease progressed. Despite his health problems, Chopin composed and performed until 1848 , when he had his last concert. 


\section{SCHERZO NO 1 IN B MINOR, OP 20}

Historical background:

The scherzo developed from the minuet, gradually replacing it as the $3^{\text {rd }}$ movement in symphonies, sonatas and similar works. The form of a scherzo is a rounded binary form but it is usually played with the accompanying Trio, followed by a repeat of the Scherzo, creating a ternary form ( $\mathrm{ABA})$. Romantic composers also began to write scherzi as pieces by themselves, stretching the boundaries of the form.

Analysis:

Chopin's Scherzo in B minor Op. 20 is a dramatic and brilliant piece with clearly distinguished sections and a highly developed coda. The first section of a scherzo consists of rapid passages, which are of great emotional intensity as well as of technical difficulty. Chopin's ingenious approach to the melody is obvious through the scherzo in the melodic treatment of accents. The accents in this scherzo almost always create a hidden melody in the inner voices (measures $94-124$ ). This polyphonic approach to the texture brings complexity but it is never overused. Chopin's texture is always elegant and clear, almost classical. The great expressiveness and the range of emotions are what make Chopin a true Romantic. The Trio vividly contrasts with the rest of the piece by its calm and poetic nature. The theme of the Trio is based on the popular Polish Christmas carol Lujaze Jezuniu (sleep little Jesus). The theme of the Trio is in the inner voice, which brings a certain technical problem as the theme is to be performed by the thumb of the right hand. As the theme is lyrical and calm and there is a Chopin's mark to be played legato (which 
can't be done with one finger, a thumb in this case), good pedal technique is of great use. This is a typical romantic approach to the texture when certain impression of a sound (legato) should be created even if that is physically impossible. The coda of the Scherzo is the most technically demanding part of the work but also the most passionate one. The culmination of the coda is the chord in measure 594 repeated through the measure 599, the German augmented chord leading to V7. 


\section{LIST OF REFERENCES:}

Little, Meredith and Natalie Jenne.1991. Dance and the Music of J.S.Bach. Bloomington, IN: Indiana University Press.

Gillespie, John.1972. Five Centuries of Keyboard Music. Mineola, NY: Dover Publications, Inc.

Scott, Marion M.1974. Beethoven. London, GB: J.M. Dent \& Sons LTD.

Kelley, Edgar Stillman.1969. Chopin the Composer. New York, NY: Cooper Square Publishers, Inc. 